\title{
THE EFFECT OF SELF-REGULATED LEARNING (SRL) ON ACADEMIC PROCRASTINATION IN CLASS XI STUDENTS OF SMA NEGERI 2 PURBALINGGA, INDONESIA
}

\author{
M. Salim Anwar \\ University of Muhammadiyah Purwokerto, Indonesia \\ salimanwar377@gmail.com \\ Retno Dwiyanti \\ University of Muhammadiyah Purwokerto, Indonesia
}

\begin{abstract}
Academic procrastination is one of the problems experienced by students, which is caused by feeling tired or bored. While on the other hand, students need the ability to organize themselves to achieve their goals. This study aims to determine the effect of self-regulated learning on academic procrastination in class XI students of SMA Negeri 2 Purbalingga. The hypothesis proposed in this study is that self-regulated learning has a significant effect on academic procrastination in class XI students of SMA Negeri 2 Purbalingga. The sample of this research is the students of class XI SMA Negeri 2 Purbalingga with a total of 80 students. Data were collected by using several instruments in the form of academic procrastination scale and self-regulated learning scale. The academic procrastination scale has a reliability of 0.741 and a self-regulated learning scale of 0.744 . The results of the analysis show that the calculated $F$ is 146.734 with a coefficient of $p=0.000(p<0.01), t=-12.113$. It can be concluded that the hypothesis is accepted, namely that there is a significant influence between self-regulated learning on academic procrastination in class XI students of SMA Negeri 2 Purbalingga and self-regulated learning. It has an effect of $65.3 \%$ on academic procrastination $(R=s q u a r e=0.653)$. For educational institutions, the results of this study can be a contribution to the thought of psychology to design various learning methods that lead to the concept of self-regulation in student learning in order to reduce academic procrastination.
\end{abstract}

Keywords: Academic Procrastination, Self-Regulated Learning, Students 


\section{Introduction}

Education is a process or form of the effort carried out by a person to develop their potential. One of the places to get formal education is by taking high school or Sekolah Menengah Atas (SMA) (Santika \& Sawitri, 2016). The COVID-19 pandemic that is happening today is a tragedy for the entire population of the earth, including Indonesia. This tragedy causing several impacts, one of which is in education, that begin to apply a new system called an online class system (Aji, 2020). One of the student behaviors that emerged during this pandemic period was that students paid less attention to their academic affairs. This can be seen from their habit of spending more time at night, facing television for hours, being addicted to online games to delaying work assignments. The habit of delaying tasks carried by individuals can determine the success or failure of each individual, especially in completing academic tasks which is known as procrastination (Savira \& Suharsono, 2013).

Solomon and Rothblum (1984), mention that academic procrastination can cause various negative impacts. It is will provide various losses for students including assignments that are not completed, or are completed but the results are not optimal due to deadlines. Procrastination can also cause anxiety that can lead to depression, either when doing assignments or when facing exams. Students become less focused on the assignments and exams, thus allowing a high number of mistakes and a lot of wasted time. Procrastination can also cause difficulty in concentrating because there is a feeling of anxiety, so learning motivation and self-confidence are low (in Lubis, 2018).

Based on previous research conducted by (Khotimah et al., 2016) on students of SMP (Junior High School) in Malang, it was found that students still use the "Overnight Speed System" in learning: doing assignments one day before being collected, doing assignments at school before the bell rings, chatting while working on assignments and late submission of the assignments. The results of the data analysis of academic procrastination of junior high school students in Malang by the researchers themselves showed that $81.5 \%$ of students experienced academic procrastination in the moderate category, and $1 \%$ of the 395 sample students experienced academic procrastination in the high category. It can be concluded that procrastination acts are mostly carried out by individuals, in this case regardless of age, gender, or status as a student or even a worker.

The preliminary was study conducted by using a questionnaire distributed via Google form which was filled up by $76.5 \%$ female students, and $23.5 \%$ male students. Based on preliminary study data, $83.5 \%$ of students have a tendency to delay in completing tasks, while the other $16.5 \%$ have a tendency to delay in starting work. Academic procrastination is one of the problems experienced by students, which is caused by feeling 
tired or bored. While on the other hand, students need the ability to organize themselves to achieve their goals(Dwi Kencana Wulan, 2016).

Academic procrastination in students can be caused by selfregulation in learning or Self-Regulated Learning (SRL) (Alfina, 2014). Previous research by (Hanifah \& Rusmawati, 2019) explained that there was a decrease in academic procrastination behavior of students in SMP Negeri 33 Semarang after being given selfregulated learning training.

Another study conducted by Wulan (2016), stated that based on statistical testing, there was a significant effect of self-regulation in academic procrastination of class $X$ SMA Negeri 10 Jakarta. The resulting influence is negative, which means that the higher the self-regulation, the lower the Academic Procrastination. The effect of self-regulation on academic procrastination is $29.3 \%$ and the other $70.7 \%$ is influenced by other factors not examined in this study.

Based on the description of the background, the authors are interested in conducting research with the title "The Effect of Self-Regulated Learning (SLR) on Academic Procrastination in class XI students of SMA Negeri 2 Purbalingga".

\section{Theoretical Framework}

According to Ferrari (1995), procrastination is an activity to delay action, especially when there is no clear reason. Procrastination is an act of voluntarily delaying the activities that should be done without thinking about the worse consequence(Surijah \& Tjundjing, 2007).

According to Solomon and Rothblum (1985), academic procrastination is a behavior ofconsciously delaying academic tasks by doing other activities that are fun and unimportant, not purposeful, unable to pay attention to time so that it has a negative impact to the point of causing loss to its perpetrator. It will form a tendency to delay doing or completing tasks as a whole to carry out other useless activities, so it hampers the process of completing the tasks and is often not completed on time (in Ulum, 2016).

Aspects of academic procrastination according to Surijah and Tjundjing(in Ulum, 2016) consist of 4 things, namely: 1 ) perceived time, is a tendency of a procrastinator, one of which fails to meet deadlines; 2) Intention-action gap, is the gap between desire and behavior; 3) Emotional distress, is one of the visible aspects of feeling anxious when procrastinating; 4) Perceived ability, is a belief in one's own abilities.

There are several factors that can cause academic procrastination. Park and Sperling (in Cinthia \& Kustanti, 2017) state that procrastination is influenced by 2 factors, namely internal and external factors. That are including 1) internal factors: poor self-regulation, behavior to avoid tasks caused by low beliefs of self-ability; 2) external factors: Anxiety or fear, the difficulty of making decision, less assertive, afraid of failure, and perfectionism. 
Pintrich and Groot (1990) provide the term 'self-regulated in learning' or SRL in short. The concept of selfregulation was first proposed by Bandura in the background of social learning theory. According to Zimmerman (2002), in the learning process, self-regulation is not a mental ability or skills in academicbut an effort of managing individual learning processes through setting and achieving goals with reference to awareness and independent behavior in active learning. Self-regulation learning consists of metacognition, motivation, and planned actions which are cycled adapted to achieve personal goals (in Savira \& Suharsono, 2013).

According to Slavin (2011), selfregulated learning means "students who have knowledge of effective learning strategies and how and when to use them". Furthermore, according to Santrock (2010) "self-regulation learning is generating and monitoring one self's thoughts, feelings, and behavior to achieve a goal" (in Yulianti et al., 2016)

According to Zimmerman (in Alfina, 2014) aspects of self-regulated learning consist of three parts: 1) Metacognition, is an ability possessed by each individual related to the process of planning, organizing or regulating, self-instructing, monitoring and evaluating in study activities; 2) Intrinsic motivation, which is a motivation that arises within the individual itself without any element of coercion or encouragement from other parties, but on the basis of his own will. Intrinsic motivation can be created by pursuing the feeling of curiosity, the desire to try and progress in learning. 3) Active Learning Behavior, is a way to students to doso that they can understand what they are learning during the learning process and after the learning process is complete.

\section{Research Methodology Variable}

The dependent variable in this study is academic procrastination, while the independent variable is selfregulated learning.

\section{Subject}

The research subjects were 80 students of class XI SMA Negeri 2 Purbalingga. The approach used to select the sample is cluster random sampling. The methodology of this research is quantitative research. Quantitative research methods can be interpreted as a research method based on the philosophy of positivism. It is used to examine certain populations or samples, data collection using research instruments, statistical data analysis, with the aim of testing the established hypothesis (Sugiyono, 2012).

\section{Data Collection Methods and Instruments}

In this study, the method used for data collection is by using the academic procrastination scale and self-regulated learning scale as follows:

Academic procrastination scale is a tool to measure the level of academic procrastination. The academic procrastination scale is based on aspects, namely perceived time, 
intention-action gap, emotional distress, and perceived ability. The scale is compiled by using the Likert scale model. The answers to the questions are made up of five categories, for the scale in this study, namely the academic procrastination scale, namely Strongly Disagree, Disagree, Neutral, Agree, and Strongly Agree. The scale consists of favorable and unfavorable questions.

The self-regulated learning scale is based on aspects such as metagonization, intrinsic motivation, and active learning behavior. The scale is also compiled by using the Likert scale model. The answers to the questions are made up of five categories, for the scale in this study, namely the academic procrastination scale, namely Strongly Disagree, Disagree, Neutral, Agree, and Strongly Agree. The scale consists of favorable and unfavorable questions.

The data collection method used instruments in the form of an academic procrastination scale that had a reliability of 0.741 and self-regulated learning scale that had a reliability of 0.744 .

\section{Data Analysis Method}

The data analysis technique used in this research is linear regression analysis using SPSS version 16.00 .

\section{Result and Discussion}

Based on the results of the data collected in class XI SMA Negeri 2 Purbalingga, it obtained demographic data of respondents as follows:
Table 1. Gender Demographic Diagram

\begin{tabular}{clcc}
\hline No & Gender & Amount & Percentage \\
\hline 1. & Male & 30 & $37,5 \%$ \\
2. & Female & 50 & $62,5 \%$ \\
\hline & Total & 80 & $100 \%$ \\
& & & \\
\hline
\end{tabular}

Based on the diagram above, the results show that there are fewer female respondents in this study than male. The ratio is $37.5 \%$ male and $62.5 \%$ female.

Table 2. Class Demographic Diagram

\begin{tabular}{lrcl}
\hline No & Class & Amount & Percentage \\
\hline 1. & Social 1 & 22 & $27,5 \%$ \\
2. & Social 2 & 10 & $12,5 \%$ \\
3. & Social 3 & 11 & $13,8 \%$ \\
4. & Social 4 & 7 & $8,8 \%$ \\
5. & Social 5 & 12 & $15 \%$ \\
6. & Social 6 & 18 & $22,5 \%$ \\
& & & \\
\hline & & & $100 \%$ \\
\hline
\end{tabular}

Based on the diagram above, the results show that the respondents are from class XI IPS which consists of 6 classes.

Data analysis by using regression analysis as follows:

Table 3. Results of Regression Analysis

\begin{tabular}{|c|l|c|l|l|}
\hline $\mathrm{F}$ & \multicolumn{1}{|c|}{$\mathrm{T}$} & $\mathrm{P}$ & Determination & $\begin{array}{c}\mathrm{R} \\
\text { square }\end{array}$ \\
\hline 146.734 & $\begin{array}{l}- \\
12.113\end{array}$ & .000 & Significant & 0.653 \\
\hline
\end{tabular}

Based on the results of the analysis in table 1, it is known that there is a negative effect of self-regulated 
learning on academic procrastination $(F=146,734 ; t=-12,113 ; p=0.000)$ which means that the variable is significant $(P<0.05)$. This is in line with the research conducted by Ulum (2016) which proves that the self-regulated learning strategy isan effective way in reducing the level of student academic procrastination. It means that the level of academic procrastination of the experimental group that was given the self-regulated learning strategy experienced a significant decrease compared to the control group which was not given the self-regulated learning strategy. This decrease was also applied in every aspect of students' academic procrastination, namely: delay in doing or completing assignments, time gaps between plans and actual work, doing other activities that are more enjoyable, fear of failure, and lack of motivation.

The results of the analysis above were also shown $\mathrm{R}$ square $=0.653$. It proves that there is an effect of selfregulated learning on academic procrastination in class XI students of SMA Negeri 2 Purbalingga by $65.3 \%$, while the other $34.7 \%$ were influenced by other variables that were not examined in this study. As the research conducted by Nuruddin (2014), states that based on the results of the analysis that has been carried out, it can be concluded that self-efficacy has a negative relationship with academic procrastination behavior, which means that the higherthe level of student academic self-efficacy, the lowerthe student's academic procrastination.

\section{Conclusion}

Based on the results of data analysis obtained $\quad(F=146.734 ; \quad t=-$ 12,$113 ; p=0.000$ ), it can be concluded that there is a significant negative effect $(p<0.05)$ between self-regulated learning on academic procrastination in class XI students of SMA Negeri 2 Purbalingga. It means the higher the level of self-regulated learning, the lower the student's academic procrastination, and vice versa. The coefficient of determination is 0.653 , which means that self-regulated learning has an effective contribution of $65.3 \%$, while the remaining $34.7 \%$ can be influenced by other factors that were not examined in this study.

\section{Implication}

The results of this study also provide implications for the application of research results in everyday life as follows:

1. The role of educational institutions in helping students develop independent learning abilities in the learning process by monitoring and assisting students in providing strategies that can be carried out by students in achieving goals in learning.

2. For educational institutions, the results of this study can be a contribution to the thought of psychology to design various learning methods that lead to the concept of self-regulation in student learning in order to reduce academic procrastination.

3. Students are able to improve selfregulation in learning independently 
by setting learning goals to be achieved and strategies that can assist in achieving them.

\section{Suggestion}

The limitation of this study is that the subject is still not comprehensive because it only covers 1 batch. In addition, this study has not been able to examine in detail every aspect of the research variables and also has not studied in detail the demographics of the students of SMA N 2 Purbalingga. So that further researchers are expected to be able to examine more related to the demographics of SMA N 2 Purbalingga students and be able to examine other variables. 


\section{References}

Aji, R. H. S. (2020). Dampak Covid-19 pada Pendidikan di Indonesia: Sekolah, Keterampilan, dan Proses Pembelajaran. SALAM: Jurnal Sosial Dan Budaya Syar-I, 7(5), 395-402. https://doi.org/10.15408/sjsbs.v7i5 .15314

Alfina, I. (2014). Hubungan SelfRegulated Learning dengan Prokrastinasi Akademik pada Siswa Akselerasi. EJournal Psikologi, 2(2), 60-66.

Cinthia, R. R., \& Kustanti, E. R. (2017). Hubungan Antara Konformitas Dengan Prokrastinasi Akademik Pada Mahasiswa. Jurnal Empati, 6(April), 31-37.

Dwi Kencana Wulan, P. R. A. A. (2016). Pengaruh Regulasi Diri Terhadap Prokrastinasi Akademik Pada Siswa SMA. Perspektif Ilmu Pendidikan, 30(2), 67-76. https://doi.org/10.21009/pip.302.1

Ferrari, J. R., Johnson, J. L., \& McCown, W. G. (1995). Procrastination And Task Avoidance.

Hanifah, F., \& Rusmawati, D. (2019). Pengaruh Pelatihan Self-Regulated Learning terhadap Prokrastinasi Akademik pada Siswa SMP Negeri 33 Semarang. Jurnal Empati, 8(2), 124-130.

Khotimah, R. H., Radjah, C. L., \& Handarini, D. M. (2016). Hubungan Antara Konsep Diri Akademik, Efikasi Diri Akademik, Harga Diri Dan Prokrastinasi Akademik Pada Siswa SMP Negeri Di Kota Malang.
Jurnal Kajian Bimbingan Dan Konseling, 1(2), 60-67. https://doi.org/10.17977/um001v1 i22016p060

Lubis, I. S. L. (2018). Hubungan Regulasi Diri dalam Belajar dan Efikasi Diri dengan Prokrastinasi Akademik Mahasiswa. Jurnal Diversita, 4(2), 90.

https://doi.org/10.31289/diversita. v4i2.1884

Santika, W. S., \& Sawitri, D. R. (2016). Self-Regulated Learning Dan Prokrastinasi Akademik Pada Siswa Kelas Xi Sma Negeri 2 Purwokerto. Empati, 5(1), 44-49.

Savira, F., \& Suharsono, Y. (2013). SelfRegulated Learning (SRL) Dengan Prokrastnasi Akademik Pada Siswa Akselerasi. Jurnal Ilmiah Psikologi Terapan, 01(01), 66-75. https://doi.org/10.1017/СВ097811 07415324.004

Sugiyono. (2012). Metode Penelitian Kuantitatif Kualitatif Dan R\&D.

Surijah, E. A., \& Tjundjing, S. (2007). Mahasiswa Versus Tugas: Prokrastinasi Akademik dan Conscientiousness. Anima, Indonesian Psychological Journal, 22(4),352-374.

https://www.researchgate.net/publ ication/275715751_Mahasiswa_Ver sus_Tugas_Prokrastinasi_Akademik _dan_Conscientiousness/link/5545 1c8b0cf23ff71686997a/download

Ulum, M. I. (2016). Strategi SelfRegulated Learning untuk Menurunkan Tingkat Prokrastinasi 
Akademik Siswa. Psympathic:

Jurnal Ilmiah Psikologi, 3(2), 153170.

https://doi.org/10.15575/psy.v3i2. 1107
Yulianti, P., Sano, A., \& Ifdil. (2016). Self Regulated Learning Siswa Dilihat dari Hasil Belajar. Jurnal Educatio: Jurnal Pendidikan Indonesia, 2(April), 98-102. 